\title{
Drug Abuse and Mental Stability as Predictors of Study Habit of Undergraduates at Babcock University, Nigeria
}

\author{
Fadekemi E. ADEKUNLE Ayodele KOLAWOLE \\ Babcock University, Ilisan-Remo, Ogun State, Nigeria
}

\begin{abstract}
The study examines drug abuse and mental stability as predictors of study habit of undergraduates at Babcock University. The study adopted the descriptive survey design. A well-developed, valid and reliable questionnaire was administered to collect data from the respondents. The data obtained were analyzed using the using simple percentage and frequency count, t-test and regression analysis with the aid of the software SPSS version 20, which was selected by the researcher because of its simplicity and relevance to the research work. Findings from the study reveal that Drug abuse and mental stability will significantly combine to predict undergraduates study habits $(\mathrm{F}$ $(2,301)=83.320, \mathrm{P}<.05)$; Drug abuse will not significantly predict undergraduates study habits $(\mathrm{Beta}=.054$, $\mathrm{t}=.940, \mathrm{P}<.05)$; Mental stability will significantly predict undergraduates study habits $(\mathrm{Beta}=.438, \mathrm{t}=8.469$, $\mathrm{P}<.05)$; There is a significant difference in drug abuse between male and female undergraduates $(\mathrm{t}=5.759, \mathrm{P}<.05)$; There is a significant difference in mental ability between male and female undergraduates $(\mathrm{t}=2.947, \mathrm{P}<.05)$; There is a significant difference in study habits between male and female undergraduates $(\mathrm{t}=3.159, \mathrm{P}<.05)$. The study concludes that drug abuse and mental stability serves as predictors of study habit of undergraduates at Babcock University. To this end, the study suggested that Babcock University should sensitize their students so that they will know that hard work secures success in life and they should be serious with their studies, in order to be useful to themselves, their families and the country at large.
\end{abstract}

DOI: $10.7176 / \mathrm{JEP} / 11-32-04$

Publication date: November $30^{\text {th }} 2020$

\section{INTRODUCTION}

Academic success occupies a very important place in education as well as in the learning process. It is considered as a key criterion to judge one's total potentialities and capacities which are frequently measured by the examination results (Ayodele ,2018 and Yenagi, 2012). It is used to pass judgment on the quality of education offered by academic institutions. In fact, it is still the most topical debate in higher learning institutions that caused great concern to educators and researchers due to the alarming examination performance of students (Nuthana and Yenagi, 2012).

Study habit has been seen as the pattern of behavior adopted by students in the pursuit of their studies that serves as the vehicle of learning. It is the degree to which the student engages in regular acts of studying that are characterized by appropriate studying routines (e.g. reviews of material, frequency of studying sessions, etc.) occurring in an environment that is conducive to studying (Crede and Kuncel, 2013). In short, study habits of students are determined through their time management ability, work methods, attitudes toward teachers, mental stability, drug use and acceptance of education. There are several predictors of study habits, but this current study will focus on drug abuse and mental stability

Drug abuse among undergraduate students in Nigerian higher institutions of learning has become an embarrassing occurrence to parents, schools, government authorities, and the general public (Obiamaka, 2014). The constant abuse of drugs among this group of students can cause mental instability (Obiamaka, 2014). WHO (2013) stated that $22.1 \%$ of undergraduates abuse drugs. Today, more Nigerian undergraduates are becoming drug dependants, while Nigeria gradually transits from the status of a drug-consuming nation to that of a drug-producing one. It is no longer news that undergraduates now practice the use of substance like heroin and cocaine which will invariably influence mental stability. Others substances like Indian hemp, which is frequently produced in Nigeria and other substances like Methamphetamine and tablet with codeine capable of intoxicating are mostly found in schools (Staff, 2012).

Even with this social history, no study has been carried out on drug abuse and mental stability as predictors of study habit among undergraduates in Nigeria, hence the need for this study.

Objectives of the study

1. To assess the combined predictive power of drug abuse and mental stability of undergraduates' study habit.

2. To examine the extent to which drug abuse will predict undergraduates study habit.

3. To examine the extent to which mental stability will predict undergraduates study habit.

4. To determine difference in drug use between male and female undergraduates.

Research questions

The research questions of this study are as follows; 
1. To what extent would drug abuse and mental stability combine to predict undergraduate study habit?

2. Would drug abuse significantly predict undergraduate study habit?

\section{Research Hypothesis}

$\mathrm{H}_{\mathrm{O} 1}$ : Drug abuse and mental stability will not significantly combine to predict Babcock University undergraduates' study habits

$\mathrm{H}_{\mathrm{O} 2}$ : Drug abuse will not significantly predict Babcock University undergraduates' study habits

$\mathrm{H}_{\mathrm{O} 3}$ : Mental stability will not significantly predict undergraduates study habits

$\mathrm{H}_{\mathrm{O} 4}$ : There is no significant difference between male and female Babcock University undergraduates in the influence of drug abuse and study habits.

Ho5: There are no significant relationships among drug abuse, mental stability and Study Habit.

\section{RESEARCH METHODOLOGY}

\section{Research Design}

This research work followed a descriptive survey design. The descriptive survey design deals with the systematic collection of facts from a target audience or population.

\section{Population of the study}

The population of study shall comprise of the entire undergraduate students of Babcock University.

\section{Sample and sampling technique}

The sampling method to be used for the study is purposive sampling with a sample size of 320 students. The total sample size for this study is 320 respondents.

\section{Instrument}

The research instrument that will be used for this study is questionnaire. The questionnaire was titled: "Drug abuse and mental stability as predictors of study habit of undergraduates of Babcock University." and divided into two (2) sections covering the research questions. The measuring scale for the instrument was a 4-point scale: Very likely, likely, undecided, not likely. The test-retest method was used to validate the reliability of the instrument and a cronbach's alpha value of 0.82 was obtained which indicates that the instrument was very reliable.

\section{Method of data analysis}

Data collected were analyzed using simple percentage, frequency count and inferential statistics was done using ttest $(\mathrm{P}<0.05)$ and regression analysis to test formulated hypothesis with the aid of the software SPSS version 20.

\section{RESULTS}

Results of Demographic Data of respondents are presented in Table 1.1.1 which revealed that a majority of the respondents $(57 \%)$ were female, while $43 \%$ of the respondents were male. This indicates that there were more female than male participants in this study. The greatest proportion of the respondents (40\%) were 21-25 years old. This was successively followed by those who were 15-20 years old (32\%), $26-30$ years old (20\%), and 31 years old and above $(8 \%)$. The greatest proportion of the respondents $(28 \%)$ were 200 level students. This was successively followed by 300 level students (24\%), 100 level students (19\%), 400 level students (16\%), and 500 level students (13\%). An over whelming majority of the respondents (84\%) said they were single while $16 \%$ of the respondents were married. Finally, the greatest proportion of the respondents $(31 \%)$ was from the school of education and Humanities this was successively followed by computing and Engineering (20\%), Medicine (16\%), Nursing Science (16\%), and social sciences (16\%).

Table 1.1.1: Frequency Distribution of Participants' Demographic Data

\begin{tabular}{|l|l|l|l|l|}
\hline S/N & Variable & Category & Frequency & Percentage \\
\hline 1. & Gender & Male & 131 & 43.1 \\
& & Female & 173 & 56.0 \\
\hline 2. & Age (years) & $15-20$ & 98 & 32.2 \\
& & $21-25$ & 121 & 39.8 \\
& & $26-30$ & 62 & 20.4 \\
\hline 3. & Level of Study & $31 \&$ Above & 23 & 7.6 \\
& & 100 Level & 59 & 19.4 \\
& & 200 Level & 85 & 28.0 \\
& & 300 Level & 72 & 23.7 \\
\hline 4. & Marital Status & 400 Level & 49 & 16.1 \\
& & 500 Level & 39 & 12.8 \\
\hline
\end{tabular}




\begin{tabular}{|l|l|l|l|l|}
\hline S/N & Variable & Category & Frequency & Percentage \\
\hline 5. & School & Medicine & 49 & 16.1 \\
& & Computing \& Engineering & 62 & 20.4 \\
& & Education \& Humanities & 95 & 31.3 \\
& & Nursing Sciences & 49 & 16.1 \\
& Social Sciences & 49 & 16.1 \\
\hline
\end{tabular}

Source: Field survey, 2019

Table 1.2.1: Model summary and coefficients of the multiple regression Analysis for the prediction of study Habits by Drug Abuse and mental stability

\begin{tabular}{|l|l|l|l|l|l|}
\hline Model & Sum of squares & DF & Mean square & F & Sig. \\
\hline Regression & 7443.325 & 2 & 3721.663 & 83.320 & .000 \\
Residual & 13444.724 & 301 & 44.667 & & \\
Total & 20888.049 & 303 & & & \\
\hline \multicolumn{2}{|l|}{ Model Summary: $\mathrm{R}=.597 ; \mathrm{R}^{2}=.356 ; \mathrm{R}^{2}(\mathrm{Adj})=.352 ;$ Std. Error $=6.68333$} \\
\hline
\end{tabular}

Dependent Variable: Study Habits; Predictors: (Constant), Drug Abuse, Mental Stability.

Results in Table 1.2.1 were significant $(\mathrm{F}(2,301)=83.320, \mathrm{P}<.05)$. The null hypothesis which stated that drug abuse and mental stability will not significantly combine to predict undergraduates study habits is therefore rejected in favour of the alternative hypothesis leading to the conclusion that drug abuse and mental stability will significantly combine to predict undergraduates study habits. Table 1.2.1 further indicated that drug abuse and mental stability accounted for $35.2 \%$ of the variance in study habits. (Adj. $\mathrm{R}^{2}=.352$ ).

Hypothesis Two

Ho2: Drug abuse will not significantly predict undergraduates study habits.

Table 1.2.2 Coefficients of the Regression Analysis for the prediction of study Habits by Drug Abuse

\begin{tabular}{|l|l|l|l|l|l|}
\hline Model & Unstandardized & Std. Error & Beta & T & Sig. \\
\hline Constant & 27.245 & 2.630 & & 10.360 & .000 \\
Drug Abuse & .162 & .172 & .054 & .942 & .347 \\
\hline
\end{tabular}

Dependent Variable: Study habits Predictors: (Constant), Drug Abuse

Table 1.2.2 Revealed non-significant results $($ Beta $=.054, \mathrm{t}=.940, \mathrm{P}<.05)$. The null hypothesis is therefore upheld, leading to the conclusion that drug abuse will not significantly predict undergraduates study habits

Hypothesis Three

Ho3: Mental stability will not significantly predict undergraduates study habits.

Table 1.2.3: Coefficients of the Regression Analysis for the prediction of study habits by mental stability.

\begin{tabular}{|l|l|l|l|l|l|}
\hline Model & Unstandardized & Std. Error & Beta & T & Sig. \\
\hline (Constant) & 12.762 & 2.043 & & 6.246 & .000 \\
Mental Stability & .625 & .074 & .438 & & .000 \\
\hline
\end{tabular}

Dependent Variable: study Habits; Predictors: (Constant), Mental Stability

Table 1.2.3 revealed significant results $($ Beta $=.438, \mathrm{t}=8.469, \mathrm{P}<.05)$. The null not significantly predict undergraduates study habits is therefore rejected in favours of the alternative hypothesis, leading to the conclusion that mental stability will significantly predict undergraduates study habits. Table 1.2.3 further showed that study habits could be predicted from mental stability by means of the regression equation.

Study Habits $=(0.625$ X Mental Stability $)+12.762$.

Hypothesis Four

Ho4: There is no significant difference in drug abuse between Male and Female undergraduates

Table 1.2.4: Independent t-text for difference in Drug Abuse between Male and Female undergraduates.

\begin{tabular}{|l|l|l|l|l|l|l|}
\hline & N & Mean & Std. Dev. & DF & t & Sig. \\
\cline { 1 - 4 } Male & 131 & 14.0229 & 2.85405 & 302 & 5.759 & .000 \\
\cline { 1 - 3 } Female & 173 & 15.7903 & 2.455619 & & & \\
\hline
\end{tabular}

Table 1.2.4 revealed significant results $(\mathrm{t}=5.759, \mathrm{P}<.05)$. The null hypothesis which stated that there is no significant difference in drug abuse between male and female undergraduates is therefore rejected in favour of the alternative hypothesis. It is subsequently concluded that there is a significant difference in drug abuse between male and female undergraduates. This finding indicates that female undergraduates $(\mathrm{Mean}=15.8)$ scored higher on drug abuse than their male counterparts $($ mean $=14.0)$.

\section{Hypothesis Five}

Ho5: There is no significant difference in mental stability between male and female undergraduates.

Table 1.2.5: Independent t-test for difference in mental stability between male and female undergraduates.

\begin{tabular}{|l|l|l|l|l|l|l|}
\hline & N & Mean & Std. Dev. & DF & T & Sig. \\
\cline { 1 - 5 } Male & 131 & 28.2061 & 6.17653 & 302 & 2.947 & .003 \\
\hline Female & 173 & 26.2428 & 5.40768 & & & \\
\hline
\end{tabular}


Table 1.2.5 revealed significant results $(\mathrm{t}=2.947, \mathrm{P}<.05)$. The null hypothesis which stated that there is no significant difference in mental stability between male and female undergraduates is therefore rejected in favour of the alternative hypothesis leading to the conclusion that there is a significant difference in mental ability between male and female undergraduates, with the males being more mentally startle (Mean =28.2) than female undergraduates (Mean $=26.2)$.

\section{Hypothesis Six}

Ho6: There is no significant difference in study habits between male and female undergraduates.

Table 1.2.6: Independent t-text for difference in study Habits between male and female undergraduates

\begin{tabular}{|l|l|l|l|l|l|l|}
\hline & $\mathrm{N}$ & Mean & Std. Dev. & DF & T & Sig. \\
\cline { 1 - 5 } Male & 131 & 27.9771 & 7.59399 & 302 & 3.159 & .002 \\
\cline { 1 - 4 } & 173 & 30.9711 & 8.60059 & & & \\
\hline
\end{tabular}

Table 1.2.6 revealed significant results $(\mathrm{t}=3.159, \mathrm{P}<.05)$. As such, the null hypothesis which stated that there is no significant difference in study habits between male and female undergraduates is rejected in favour of the alternative hypothesis. It is subsequently concluded that there is a significant difference in study habits between male and female undergraduates with female undergraduates (mean $=31.0$ ) having a letter study habit than male undergraduates $($ mean $=28.0)$.

\section{DISCUSSION OF FINDINGS}

The results showed that respondents coherently agreed that drug abuse and mental stability serves as predictors of study habit of undergraduates at Babcock University.

The regression analysis result showed that drug abuse and mental stability serves as robust predictors of study habit of undergraduates at the institution under focus. Drug abuse and mental stability is significantly associated with predicator's of study habits. The more appropriately undergraduate run away from drugs, the better the study habit. More explicitly, the result showed that drug abuse and mental stability will significantly combine to predict undergraduates study habits $(\mathrm{F}(2,301)=83.320, \mathrm{P}<.05)$, implying that drug abuse and mental stability process would result in improved poor study habit. Secondly, the result showed that drug abuse will not significantly predict undergraduates study habits $(B e t a=.054, \mathrm{t}=.940, \mathrm{P}<.05)$. This means that not all undergraduates that abuse drugs will have a poor study habits, there is great tendency for some undergraduates abusing drugs to have a fair of good study habit. Thirdly, mental stability will significantly predict undergraduates study habits (Beta $=.438, \mathrm{t}$ $=8.469, \mathrm{P}<.05)$. This depicts that mental stability greatly drives successful performance of student's mental function, resulting in productive activities, fulfilling relationships with other people, and providing the ability to adapt to change and cope with adversity while the poor mental stability drives undergraduate poor study habits. Fourthly, There is a significant difference in drug abuse between male and female undergraduates $(t=5.759, \mathrm{P}$ $<.05)$. This depicts that the level of drug abuse between male and female undergraduates differs. Fifthly, There is a significant difference in mental ability between male and female undergraduates $(\mathrm{t}=2.947, \mathrm{P}<.05)$. This depicts that the level of mental ability between male and female undergraduates differs. and lastly, There is a significant difference in study habits between male and female undergraduates $(\mathrm{t}=3.159, \mathrm{P}<.05)$. This means that the level of study habits between male and female undergraduates differs.

The findings of the study is consistent with the findings of Anao (2012) who discovered that drug as any substance which upon entering the body changes the body function and structure; and Carroll (2013) that drug abuse as the deliberate use of chemical substances for reasons other than intended medical purposes and which occasioned physical, mental, emotional or social impairment to the users; A drug addict is said to be someone whose life has become dependent on drugs, hence drugs abuse (Obaje 2009), that drug adductors students life becomes dependent on drugs and affects there study habits in negative way; (Louw, 2011), drugs interfere with students awareness of their unique potential and thus their interest in their career development; as well as that of Akers (1991), Ballas (2016), who drew empirical evidence from effects of drug abuse on study habit of students. Furthermore, the findings of the study aligns with the findings of studies conducted by (WHO), who sees mental stability as a conventionally a hybrid of absence of a mental disorder and presence of well-being, also sees drug abuse and mental stability significantly predicting undergraduates study habits; Kelli (2012) posits that for mental stability along with drug abuse can never enhance students to succeed in their studies, they cant be able to appropriately assimilate course content, digest it, reflect on it and be able to articulate the information in written and/or oral form in right manner; Ashish (2013) who discovered that students who ensures academic success throughout the entire year, are students who ditch bad study habits and establish good ones.

The study has provided enough empirical evidence that drug abuse and mental stability serves as predictors of study habit of undergraduates at Babcock University. The study has showed that undergraduates of Babcock University study habits can be affected with drug abuse and mental stability. The finding is consistent with past empirical studies that drug abuse and mental stability serves as predictors of study habit of undergraduates in Babcock University. 


\section{RECOMMENDATIONS}

Based on the findings of the study, the following recommendations are hereby proposed for implementation in order to eliminate the involvement of students in drug abuse. They are as follows:

1. Parents and guardians should closely monitor their children/wards so that they won't indulge in drug abuse.

2. Government should strictly enforce its existing laws against drug abuse through its regulatory agencies.

3. Schools should sensitize their students so that they will know that hard work secures success in life and they should be serious with their studies, in order to be useful to themselves, their families and the country at large.

4. Counseling education should be introduced in schools to revive those who have been engaging in the act.

5. Schools should exert intensive efforts to enlighten their students on the danger inherent in the use of hard drugs.

6. Security within the school environment should be intensified and students' bags and other luggages should be checked frequently.

\section{REFERENCES}

Abang, E. (2016). Youth Involvement in Illicit Drugs: Impact on National Development. Paper Delivered at Federal Polytechnic Auchi Student Union Week. May 22-26.

Abdullahi, S. M. (2013) Effects of Drug Abuse on Academic Performance Among Secondary School Youths in Garissa Municipality, Kenya. University of Nairobi Research Archive. http://erepository.uonbi.ac.ke:8080/handle/123456789/4749

Akus, Y. (2010) Contemporary public Issues and Nigeria as a Nation Ankpa: Roma Printing \& publishing.

American psychiatric and statistical manual of mental Disorders: Washington, D.C.American psychiatric Association.

Anao, I. B, (2012) The Effects of Alcohol Use on academic achievement in High School. Econ Educ Rev. 30 (1):115 doi:10.1016/j.econedurev.2010.06.015

Atah, T.S. and Akus, Y. (2009) A Reading text on social studies for schools and colleges. Ankpa: Mighty word Resources Nig.

Ballas, P. (2016) News and Features, Department of psychiatry, Thomas. Jefferson University Hospital, Philadelphia

Boehler, M., (2011). An evaluation of study habits of third-year medical students in a surgical clerkship. The American Journal of Surgery, Vol. 181 (3), 268-271.FIND ONLINE

Carroll, C. R. (2013) Drug Abuse in Nigeria Facts, Causes and Remedies; A paper Presented at the National Seminar on Drug Abuse Enforcement, Lagos, May.

Coleman, F. E. (2012) drug use and Abuse Among students in Tertiary Institutions. The Case of FUT, Minna, Journal of Research in National Development Vol. 8. No. 1.

Crede, M. and Kuncel, N. (2008). Study habits meta-analysis, Perspectives on Psychological Science in Press, Vol. 3 (6), 425-453.

Hassan,M, Mukhtar,A, Qureshi, S.U \& Sharif, S(2012) Impact of TQM Practices on Firm's Performance of Pakistan's Manufacturing Organizations. International Journal of Academic Research in Business and Social Sciences. 2(10) 232-259. Retrieved from www.hrmars.com/journals

Hollister WP \& McGrath JH, (2016). Patent and Portion - Precursor to modern Drug Use and Abuse. Journal of Drug issues, 1 (2) 245-254.

Lakhanpal K. and Agnihotri W. (2013) Health Psychology (5th Ed.) Indian: McGraw Hill.

Louw, D.A. (2011). Human Development. Tertiary: Cape Town

Moronkola, O. A. (2013) Essays on Issues in Health, Ibadan: Royal people Nig. Ltd.

Mutsotso, S.N. and Abenga, E.S. (2010). Study methods for improving quality learning and performance in higher education. Educational Research and Review, Vol. 5 (12), 808-813.FIND ONLINE

Nagaraju, G. (2014). Academic performance of college students: Influence of time spent studying and working. Journal of Education for Business, January/February 151-159.

NDLEA (2013). Drug safety Report. Lagos

Njoku, A.O (2014) Contemporary public Issues in Social Studies Education. Enugu,: Vivian; Redeemed Printing and Publishing Company

Nuthana, P. \& Yenagi, G. (2012). Influence of study habits, self-concept on academic achievement of boys and girls. Kartanaka Journal of Agricultural Science. Vol. 22, (5), 1135-1138.

Obiamaka, V. O. (2014). "Problem behaviours in Nigerian secondary schools", Nigeria Society for Education Psychologists (NISEP), pp. 69-75.

Okonkwo C. J, (2012). Water scarcity, Amoebiasis and Abused substances among youths of Tudun wada district, Jos south LG, Plateau state. PHC posting report. (Unpublished). 
Oluremi, O. O., (2009) The Nigerian teenage and the use of drug” African Journal of Psychiatry, 5, (1 \& 2), 21 27

Otto, E.P. (2018). Study behavior and tertiary academic achievement. Australian Journal of Teacher Education, Vol. 3 (2), Article 4. FIND ONLINE

Perkinson, R. R. (2002). Chemical Dependency Counselling, California: sage publication.

Rana, S. and Kausar, R (2011). Comparison of study habits and academic performance of Pakistani British and White British students. Pakistan Journal of Social and Clinical Psychology, Vol. 9, 21-26.

Staff N. E (2012). Drug Abuse in Nigeria Schools: A Study of Selected Secondary Institutions in Bayelsa State, South-South, Nigeria. International Journal of Scientific Research in Education (IJSRE). V.5 (3). 1.

Stephen C. (2011) Research methodology in Business and social sciences, Owerri Canon

World Health Organization (WHO), (2013). Recommended Levels of substances/drugs prevention. Statistical report. Geneva. 